COLLOQUIA $\begin{array}{r}\text { PUIA } \\ \text { PUim } \\ \text { ISTA } \\ \text { CA }\end{array}$

\title{
Nikolay Aretov
}

Institute of Bulgarian Literature
Bulgarian Academy of Sciences

Bulgarian Academy of Sciences
Sofia

\section{Enlightened Travelers and Their Mental Maps}

$\mathrm{T}$ he issue of mental mapping of Eastern Europe (Wolff 1994), posed during the Enlightenment, and the similar problem of the image of the Balkans as a periphery of Europe (Todorova 1997), are both multifaceted. This paper is dealing with just one of their various aspects - the image of the Balkans as seen from certain typical European view-points and reactions to that image in Bulgaria. The reactions to the images forged somewhere in "Europe" stem from two opposed attitudes, of acceptance and of rejection.

Let me begin from the well-known enlightened attitude towards the Balkans and the Bulgarian lands practiced by travelers in the 18th century (Lady Mary Wortley Montagu, Georgina Muir Mackenzie and Polina Irby, Comte d'Hauterive, Ruggiero Boscovich, Charles de Peyssonnel, etc.). This perspective carries one clear Orientalist stance that obviously occurred not only in written texts but also in personal encounters between representatives of the European center and the Balkan periphery, of the Modern and Pre-modern perspective. This point of view and reactions to it may be encountered in geographical textbooks, in journalism, etc.

Mental maps, offered by a group of writers from the 1880s and 1890s, were unusual and extremely interesting. The members of the group played key roles in the April uprising (1876) against Ottomans and participated in the struggle for national independence. They were all modern men and acted and wrote from a perspective of modernization. Their memoirs contained a new variation of the imagined geography of the Ottoman Empire. The description of Bulgarian lands and Bulgarian people (mainly in the work of Zakhari Stoyanov) differed from the initial ideas of the author and from the nationalistic myth that was in the process of being imposed at that 
time. In contrast, Notes on the Bulgarian Uprisings (1884-1892) obviously narrowed Bulgarian space in geographical and ethnic sense and opposed it to both Europe and Ottoman Empire, seen as land of barbarians from Asia. The second aspect is the description of the Asian parts of the Empire in the memoirs of exiles (Stoyan Zaimov, priest Mincho Kanchev). Here occurred an interesting change of perspective - in Anadolu, Bulgarian exiles occasionally adopted the view-point and even some of the ideas of European travelers and orientalists (cf. Said 1978; Аретов 2005).

After the establishment of the Bulgarian state (1878,) it attracted attention abroad. A number of foreigners came here in a new capacity. Despite the new political situation the old and well established opposites still prevailed: East (Orient) - West (Occident), Center - Periphery, Modern - Pre-modern. These new narrations also generated various reactions.

The attitude to Bulgaria adopted by the Czech historian and Slavonic scholar Constantine Jireček (1854-1918) from the time of his stay in Bulgaria (1879-1884) illustrates well the dynamics and tensions between different notions about Bulgarians and the communities they belonged to. In his texts and social gestures the idea of Slav unity in its "Central European" variation was combined with "Orientalist" discourse, that is to say with condescending and patronizing attitude of the Europeans towards the Orient. This caused reactions, such as e.g. the "Occidentalist" (cf. Buruma, Avishai 2004) discourse that lead to an interesting and important clash of positions, notions and images of the Other, dissimulating various individual and group interests and a struggle for domination.

Jireček's travel notes appeared soon in Bulgarian (Иречек 1885), translated from Czech (an explanation below the title says: "From the Czech periodical Osveta, 1883, issues 8, 9 and 10"). The name of the translator is not mentioned. This was one well written text, informative especially for foreign readers; it relates a trip of the author to the Rila monastery. The general attitude towards Bulgaria and Bulgarians was positive on the whole. It was true that, as one critic claimed, the author did not pay enough attention to the monastery itself and to the saint. Interestingly enough Jireček included a more detailed description of the monastery in his later book Travelling through Bulgaria. This book was published first in Czech in 1888, then it appeared in an abbreviated German version (1891); finally, in the Bulgarian translation by St. Argirov, with some additions by the author (cf. Иречек 1974).

Jireček declared publicly his admiration for the Bulgarian landscape, his interest in the Bulgarian past and his sympathy for Bulgarians. When reaching the monastery he even testified that he had the feeling of entering into 'il paradiso terrestre'; he was fascinated by the idea of bringing there his books, of renouncing the world, its passions and storms, and of settling 
there. Nevertheless, two paragraphs - quoted below - were apt to generate negative reactions in more exigent, more sensitive readers. They did not appear in the book Travelling through Bulgaria.

A strange feeling seizes the traveler every time he comes near the boundary of the Turkish realm. It is a realization that you still remain on the Christian and civilized soil, but not far from you in the distance begins a semi-known country with its inaccessible secrets, country where there is no personal security, no human rights, where a vigilant caution on the road is needed and where one could not go just for the sake of simple human curiosity, without a governmental sanction. I know all this from personal experience and to my mind always come the verses from I do not know which classical French tragedy, that we are here, "où finit l'Europe et commence l'Asie."

Formally Bulgaria was presented here as part of Europe, and yet too close to the boundary with uncivilized Asia. Remarkably, this strange feeling seized Jireček not far from the town of Gorna Djumaya (now Blagoevgrad), situated on the other side of that boundary. The status of the author was unquestionable; he had come as civilizer, representative of Europe and its culture, someone who did not need to remember the title of a 'classical French tragedy,' or its author.

This was not a random phrase. It was a widespread insinuation with a clear ideological implication. Its most popular variation was the famous remark by Austrian Chancellor Metternich (1773-1859) that 'Asia begins at Landstrasse' - the road out of Vienna to the east. (cf. Goldsworthy 1998: 6). In the 18th century, on his way to St. Petersburg, at the Prussian-Polish border, the French ambassador Luis-Philippe Comte de Ségur felt he had "left Europe entirely." (Wolff 1994: 6).

Another episode describing the arrival of Jireček in the village of Rila was even more obvious in its approach:

We stopped at the inn and had for dinner boiled beans with garlic, big pears and something from our preserves; then we rested for a while, down on the strawmat, of course. From time to time I continued my ethnological studies through the window. Some peasant women were standing around our bundles, they were looking at my pardessus and smiling; they were talking quietly, how the material was made and how it was tailored. For me it was strange that here children were breastfed even when they were already big enough to walk, they were at least three years old; especially in case of the youngest mothers, I was to see this later in other parts of Bulgaria. I must say that here, although only occasionally, I met people with bulging eyes, symptomatic of cretinism. (Освен това трябва да спомена, че тука, ако и нарядко, се срещат люде пулести, с поличби на кретенизъм.)

1 See La Henriade (Chant 9) de Voltaire (at www.voltaire-integral.com/Html/08/19_Chant_9. html) and Fragments et variantes du génie du christianisme de François-René Chateaubriand (at http://www.poesies.net/chateaubriangenieduchristianismevariantes.txt). 
As if he was trying to squeeze into this paragraph as many stereotypes of the clash between civilization and barbarism as possible: strange and crude food ('beans with garlic') that despite the generous nature ('big pears') visitors had to supplement with their 'preserves.' The obligatory rudimentary attributes of civilization were missing - travelers had to rest 'down on the straw-mat, of course', that is to say, on the floor. The foreigner was an educated examiner, who studied the aborigines through the window, while these were marveling at the artifacts of civilization and did not know how to raise their own children. Hence it was not strange that some of them had 'bulging eyes, symptomatic of cretinism.'

The discussed text of Jireček, together with other texts of educated Slavs, Slav scholars and Slavophiles created a particular image of Bulgaria and the Balkans. This was a place with a wonderful nature where lived peculiar people - they were at the same time relatives, "ours," "Slav brothers" and alien, natives, corrupted by the poison of the Oriental small-minded pseudointellectuals who ought to have been civilized. (What did the word "civilize" mean and who profited from this process is another question, politically, an extremely important one. Let us assume that men like Jireček and his Bulgarian opponents were not aware of it; let us leave it aside to evade explosive issues.) Civilizers were well prepared and had the necessary institutional tools to build and impose their discourse about the natives. This discourse, on the surface full of goodwill and sympathy, had a subjective intention: it created knowledge about natives that described them both, to themselves and to the Others (to 'Europe' and to the 'learned world'). After M. Foucault, E. Said and postcolonial criticism, we cannot overlook the fact that this knowledge was also power, that it was a mechanism for domination.

One part of the local intelligentsia, often educated in large Slavic centers, felt threatened and pushed out by the civilizers. They tried to create a counterdiscourse with which to oppose the outside civilizers, to repel them and to help the local intelligentsia to assume its well-deserved role. An excellent example for such an attitude is provided by Vasil Popovich (1833-1897) who tried to find arguments for his counter-discourse in the patriarchal conservatism and in the stylistics of medieval religious literature. There were other options too - such as the pro-European discourse, highlighting other ethnic components of the Bulgarian nation (proto-Bulgarians, Thracians), self-victimization, ethnic messianic role, etc. Some of these options were not entirely politically correct, because they emphasized the similarities and close relations with enemies such as Greeks (ancient and modern), and Ottoman Turks. The same reasons were barring another option - a more active proclamation of the Balkan community that would have put Bulgarians together with the mentioned enemies. And another, no less important reason: 
even when opposing the undesirable discourse, the rebelling members of the local intelligentsia agreed with some parts of it, including the "Balkans" as a mental construct. Until then, the Balkans were something that could rarely generate pride, something 'alien', Oriental, shameful for Bulgarians (as for other Christians and Slavs from the peninsula). But this is a topic for another conversation.

Among the people who opposed Jireček and the "foreign manners" was Vasil Popovich. Personal relations between the two were strained. In general Jireček was too severe towards his Bulgarians acquaintances; he was sometimes suspicious and seemingly arrogant. He made in his diary several sarcastic comments about Popovich, who sought an opportunity to pay back the ironic and conceited foreigner.

One of Popovich's texts deserves special attention. The real evidence on which it was based provokes the curiosity of the reader and indirectly unveils important features of Popovich's mentality, his convictions and internal conflicts. The short story "Възпоминание за чуждите нрави в София. Дон Жуан" (Remembering foreign manners in Sofia. Don Juan), published only recently (Попович 2000: 258-267), was a satirical portrait of a contemporary man who abandoned his pregnant mistress and fled abroad. The main character blamed his inappropriate conduct on the chickenheartedness, narrow-mindedness and intrigues of the natives. The plot is presented through the eyes of two apparently well-educated Bulgarians who not only met the foreigners and commented on their conduct but also followed them in the park. The moral judgment was reached from a conservative and patriarchal viewpoint.

One could guess that Don Juan represented Jireček. The title suggested that the main character was a foreigner, a "celebrity," "one of our enlighteners," welcomed by Bulgarians because of Jireček's Slavic studies. Eventually he left in a hurry, chased by events. As we know C. Jireček came to Bulgaria in 1879 and became Chief Secretary of the Ministry of Education, then Minister, then Chair of the Council for Education and Director of the Museum and Library. He left for Prague on 1/13 September 1884 to become head of a department at the University there.

The seduced beauty who was also a "celebrity" and later "got sick of us" as well, provokes our curiosity too. She appeared to be closely connected to the Palace; "a part of the destiny of the citizens of Sofia, not to use a bigger word," was entrusted to her. This was an allusion to Klotilda Tzvetishich, a Croatian from Zagreb, who graduated in Vienna and then became a teacher in the First Secondary School for Girls in Sofia. She got engaged to Jireček, not without some hesitations. Later he wrote a letter to her saying that his family did not approve of her, but that nevertheless he was ready to keep 
his word, if she insisted. She immediately answered informing him that she ceased to consider herself his fiancée. Without telling her, the husband of her older sister, Professor Maysnek from the University of Zagreb, went to Prague to seek an explanation from Jireček.

Today we have a rare opportunity to see the plot of the short story through the eyes of the main character. Jireček often mentioned Klotilda in his diary; obviously he was in close and friendly relations with her, but he never called her his fiancée. The motives of his departure are also explained in his letters to Marin Drinov, again without mentioning Klotilda.

Klotilda Tzvetishich's stay in Sofia did not pass without scandals. Jireček stood by her at each occasion. The behaviour of Tzvetishich and Jireček obviously irritated local patriarchal conservatives. It was not only a question of more liberal conduct, criticized from a patriarchal viewpoint. Jireček himself revealed the attitude that he and Klotilda - two well educated Slavs from Central Europe - had towards Bulgarians. The couple plunged into long conversations, when they met on the board of a ship carrying them on the Danube towards Bulgarian lands. Jireček was flattered that the young lady remembered his words: "One could get accustomed, could acclimatize oneself with the East, but one must not go out - the impressions from the West make the return to the Orient very bitter." It was obvious that here Orient meant Bulgaria, but Prague and Zagreb belonged within the borders of the West. The clever phrase, the self-flattering pose made Jireček forget even his appreciation of the beauty of nature, declared elsewhere. Nowadays it is almost impossible not to look behind such phrases and notions in the context of the radical criticism introduced by Edward Said, and of the opposition Occident - Orient.

Presumably Popovich took his revenge on the sarcastic and arrogant foreigner writing his story "Don Juan." Let me stress that all the discussed texts were not at that time published. But Popovich and Jireček had most likely said this sort of things in public and what they said could not be kept secret. Regardless whether the gossip was true or not, one could say that both of them accused each other of similar sins. It looks as if the two concepts, the two viewpoints were clashing. These were more general concepts that related not only to the woman and her relations with the man. Seemingly Jireček was more liberal, more enlightened and more European, while Popovich appeared to belong to the patriarchal conservatives. Nevertheless I think that reducing the conflict to patriarchal (old) vs. liberal (modern) conceals the real similarity between the two parties. If we go beyond the phraseology, we could see that both behaved in a similar way. Both defined the Own and the demonic Other, according to tradition. The demonization of the Other sets the rules that restrict communication with him or her. The core of this set of 
rules always contains marital and sexual restrictions. At least at some point, the forbidden becomes attractive and starts to generate some kind of images. The question is to what degree the participants in the conflict unconsciously stick to the traditional rules and to what degree they use instrumentally the discourse produced by these rules.

The similarity of the accusations probably suggests that the conflict was not only between the patriarchal and the modern "European" ethics, between Centre and Periphery, but between two similar people, obsessed with widely spread prejudice; and between representatives of the two extremes of the Slav idea - the Russian and the Central European. Liberal and conservative accusations appeared to be only arguments, weapons in still another encounter. It looked like a personal matter, but in its essence it was a conflict between two social roles, between two positions in society and between their discourses.

The first role was that of the civilizer, who came to the Orient from outside to bring and to impose the benefits of the Enlightenment. The second was that of a native representative of intelligentsia who revolted against the "civilizer" because he refused to be treated as an inferior, as the object of the civilizing. In this particular case he might have felt deprived because the role of civilizer which he played or at least rehearsed was taken away from him. One could presume that from a certain perspective, there was competition for such a role, important to both of them. As a mater of fact, both Popovich, born in Rumania and a graduate of Moscow University, and Jireček, came from the "outside," they both became adults abroad, their ambitions were similar.

To articulate their positions both of them needed to use some kind of language that already existed. The language of Popovich is reminiscent of (should I say - is used instrumentally) the discourse of fear generated by the threats of "Europeisation," if we accept the vocabulary from the time of the Bulgarian national Revival; he sought to build a more modern "Occidentalist" discourse. This put him at par with the bearers of gossips who loved to comment on the life of Tzvetishich. But behind the patriarchal intonation of the short story condemning the "foreign manners" one could notice a European vocabulary - "Don Juan," "Dulcinea" used as proper names, etc.

The other role applied clichés such as "Oriental harem's ideas," or "a semi-Byzantine character" borrowed from the European discourse about the Orient, already in existence, arrogant and full of prejudice and not impartial at all. In fact, we should ask whether the variation of the European discourse used by Jireček was indeed liberal? (After E. Said, one may even question its archetype). The foreigner was also inclined to use patriarchal arguments in his accusations against Popovich even in his personal diary, that is to say, when he was alone. His patriarchal thinking showed itself in the fact that he also failed to provide any reason for breaking his engagement 
to Klotilda. One could presume that seen from Prague, Zagreb also appeared too "Oriental." The refusal to provide an explanation probably revealed a guilty patriarchal conscience. The allusion that the enlightened bridegroomto-be in fact complied with the will of his family shows him undoubtedly as patriarchal.

It is important to notice that both discourses sought arguments blaming women. What's more, it was Klotilda Tzvetishich who suffered the most from all these events. She was forced by the situation, by the mentality dominant in the Bulgarian society and by her own convictions to abandon the desired and pre-selected role of civilizer, both in the direct and the figurative sense of the word. Although we know little about her background, her mission of "civilizer" could not have been so different from that of Jireček.

Popovich's reaction was not the only one expressed at that time. Ivan Vazov (1850-1921), the great classic of Bulgarian literature, adopted Jireček's view-point in both, his travel accounts and his fiction. He was the most important Bulgarian author of travel accounts, or at least one of the two most important (the other was the younger Aleko Konstantinov). In one of his earliest travel writings The Great Wilderness of Rila Mountain (Великата рилска пустиня, 1892), Vazov, a great Bulgarian patriot, willingly quoted Jireček as an expert on Bulgarian matters. Furthermore, he perceived him as a model and fully adopted the foreigner's view-point, including some of his less flattering observations.

With this aim I took with me... the only three or four works on Rila mountain... Rila monastery by Dr. C. Jireček...

- Look at these wild naked planes: peasants here live underground, like troglodytes... What do this people eat? May be leaves [like their goats]. Some goitrous [гушав] women and children, that appear here, complete this sad picture. (Вазов 1956: pp. $27,31,44,51$ et al.)

In conclusion, the origin and evolution of the image of the Balkans can be easily traced to the age of Enlightenment and those who travelled to the region during that time, to the 19th century visitors and finally, to the native Bulgarian authors writing about Anadolu and their homeland. Within this process, various attempts have been made to face "European" approaches toward Bulgaria and the Balkans, resulting in an "Occidentalist" discourse. We may detect as well purely personal reasons underlying both discussed attitudes of acceptance and rejection. 


\section{References}

Вазов, Ив.

Texts

(1956) Събрани съчинения. Т. 10, София.

Заимов Ст.

(1983) Миналото. Под редакцията на А. Меламед. Бележки А. Меламед. Литературни редактори-консултанти Ил. Тодоров и Сл. Иванова. София.

Иречек К.

(1885) Рилский Манастир. - “Периодическо списание,” № 18.

(1930) Български дневник. Т. 1-2, София.

(1974) (1 изд.1899) Княжество България. Т. 2. Пътувания по България. Превод Ст. Аргиров. Второ изд. под редакцията на Евлоги Бужашки и Велизар Велков, София.

Кънчев Поп Минчо

(1985) Видрииа. Спомени, записки, кореспондениия. Разчели и подготвили за печат К. Възвъзова-Каратеодорова и Т. Тихов. Второ изд. София.

Попович В.

(2000) Съчuнения. Издири и подготви за печат Н. Аретов. София.

Стоянов 3.

(1983) Записки по българските въстания. - В: Съчинения. Т. 2, София.

Аретов Н.

\section{Other References}

(1995) Българското възраждане и Европа, София.

(2001) Балкански идентичности в българската култура от модерната епоха (XIX - XX век). Към постановката на проблема [in:] Балкански идентичности в българската култура отмодерната епоха (XIX-XX век), София.

(2001) Криворазбранатацивилизаторка.ЗаединепизодотживотанаКлотилда Цветишич в София [in:] Тя на Балканите. Благоевград.

(2005) Ввобразената геограбия на Османската империя в спомените на трима български революиионери (Захари Стоянов, Стоян Заимов и Минчо Кънчев), “Slavia Meridionalis." Studia linguistica Slavica et Balcanica 5, Warszawa, pp. 113-128.

Anderson B.

(1983) Imagined Communities: Reflections on the Origin and Spread of Nationalism, London.

Buruma I. and Avishai M.

(2004) Occidentalism: A Short Story of Anti-Westernism, London.

Goldsworthy V.

(1998) Inventing Ruritania. The Imperialism of the Imagination, New Haven and London Кьосев А.

(1994) Микрометодология: Отночението "иентър - периферия" като методологически проблем на славистичната компаративистика [in:]

COLLOQUIA HUMANISTICA 153 
Studiorum Causa. Сборник по случай 50-годишнината на Радосвет Коларов. София.

Said E.

(1978) Orientalism. London \& New York.

Todorova M.

(1997) Imagining the Balkans. New York and Oxford.

Wolff, L.

(1994) Inventing Eastern Europe. The Map of Civilization on the Mind of the Enlightenment. Stanford.

\section{Просветени пътешественици и техните ментални карти}

Проблемът за менталното картографиране на Източна Европа (Л. Улф) от Просвещението, както и сродния му проблем за отношението към Балканите (М. Тодорова) имат многобройни аспекти. Статията очертава три от тях и търси връзките им, видени през опозицията ориентализъм - оксидентализъм.

В началото са представени най-общо менталните карти на българите революционери и модернизатори от XIX в. на Ориента. Те са особено характерни за мемоарите на заточениците в Диарбекир. След това вниманието се насочва към текстовете на влиятелни чужденци, попаднали в България непосредствено след 1878 г., на първо място някои публикации на чеха Константин Иречек и някои реакции към тях. Разкрити са общите елементи в ориенталистката гледна точка на чужденеца и оксиденталистките възражения на българина. Изказва се хипотезата, че в случая не се наблюдава сблъсък между традиционно (патриархално) и модерно, а конкурентна борба за ролята на „цивилизатора” на българското общество. В тази борба опонентите използват инструментално наличните дискурси, били те модернистки или патриархални, ориенталистки или оксиденталистки.

\section{Oświeceni podróżnicy i ich mapy mentalne}

Problem mentalnego kartografowania Europy Wschodniej (L. Wolff), jak też Bałkanów (M. Todorowa), od czasów oświecenia jest wieloaspektowy. Artykuł charakteryzuje trzy spośród nich i poszukuje związków pomiędzy nimi, poprzez analizę opozycji orientalizm - okcydentalizm.

Na początku prezentuję najogólniej mapy mentalne bułgarskich rewolucjonistów i przedstawicieli nowoczesności z XIX wieku na Bałkanach (Orient). Najbardziej 
charakterystyczne pod tym względem są dzienniki skazańców z twierdzy tureckiej w Diar-Bekir. Następnie moja uwaga skupia się na tekstach wpływowych cudzoziemców, którzy znaleźli się w Bułgarii bezpośrednio po 1878 roku, a wśród nich w centrum mojego zainteresowania znajdują się niektóre publikacje Czecha Konstantina Irečka i reakcje na nie.

Artykuł jest próbą zarysu punktu widzenia cudzoziemca w stosunku do przedstawicieli Orientu /Bałkanów/Bułgarii i bułgarskiego dystansu w odniesieniu do Okcydentu /Zachodu/ Europy. Materiał analizowany skłania ku hipotezie, że nie o zderzenie między tradycjonalizmem (patriarchalną kulturą) i nowoczesnością idzie, ale o konkretną walkę o odegranie roli „cywilizatora” bułgarskiego społeczeństwa. W tej walce oponenci wykorzystują instrumentalnie dostępne dyskursy, modernistyczne, czy też patriarchalne, orientalne, czy okcydentalne.

Przekład z języka bułgarskiego Jolanta Sujecka 